Supporting Information for:

\title{
Self-Threading of a Poly(ethylene glycol) Chain in a Cyclodextrin-Ring: Control of the Exchange Dynamics by Chain Length
}

\author{
Youhei Inoue, Masahiko Miyauchi, Hiroki Nakajima, Yoshinori Takashima, Hiroyasu \\ Yamaguchi, and Akira Harada* \\ Department of Macromolecular Science, Graduate School of Science, Osaka University, \\ 1-1 Machikaneyama, Toyonaka, Osaka, 560-0043, Japan \\ E-mail: harada@chem.sci.osaka-u.ac.jp
}

\section{Contents}

Measurements, Materials and Synthesis.

Characterization of 6-AmHyCiO- $\beta$-CD, 6-PEG600acid-HyCiO- $\beta$-CD, and 6-PEG3000acidHyCiO- $\beta$-CD.

Figure S1. 2D ROESY NMR spectrum of 6-PEG600acid-HyCiO- $\beta$-CD in $\mathrm{D}_{2} \mathrm{O}$.

Figure S2. 2D ROESY NMR spectrum of 6-PEG3000acid-HyCiO- $\beta$-CD in $\mathrm{D}_{2} \mathrm{O}$.

Figure S3. NMR spectra and proposed structures of 6-AmHyCiO- $\beta$-CD in the presence of AdCA in $\mathrm{D}_{2} \mathrm{O}$.

Figure S4. 2D ROESY NMR spectrum of 6-PEG600acid-HyCiO- $\beta$-CD in the presence of an equal amount of AdCA in $\mathrm{D}_{2} \mathrm{O}$.

Figure S5. NMR spectra and proposed structures of 6-PEG3000acid-HyCiO- $\beta$-CD in the presence of AdCA in $\mathrm{D}_{2} \mathrm{O}$.

Figure S6. Circular dichroism spectra of 6-PEG3000acid-HyCiO- $\beta$-CD in aqueous solutions.

Variable-temperature NMR measurement.

Figure S7. Variable-temperature NMR spectra of 6-PEG600acid-HyCiO- $\beta$-CD in the presence of a half amount of AdCA in $\mathrm{D}_{2} \mathrm{O}$.

Figure S8. Variable-temperature NMR spectra of 6-PEG3000acid-HyCiO- $\beta$-CD in the presence of a half amount of AdCA in $\mathrm{D}_{2} \mathrm{O}$.

Figure S9. Partial 2D ROESY NMR spectrum of 6-PEG600acid-HyCiO- $\beta$-CD in the presence of a half amount of AdCA in $\mathrm{D}_{2} \mathrm{O}$. 


\section{Measurements.}

The ${ }^{1} \mathrm{H}$ NMR spectra were recorded at $400 \mathrm{MHz}$ on a JEOL-GSX 400 spectrometer. The chemical shifts were referenced to the solvent values $\left(\delta=4.70 \mathrm{ppm}\right.$ for HOD, $\delta=2.50 \mathrm{ppm}$ for DMSO- $\left.d_{6}\right)$. The 2D ROESY NMR experiments were recorded at $600 \mathrm{MHz}$ on a VARIAN UNITY plus NMR spectrometer. The circular dichroism spectra were recorded on a JASCO J820 spectrometer in water with $0.1 \mathrm{~cm}$ cell at room temperature. Vapor pressure osmometry (VPO) was carried out by a GONOTEC OSMOMAT 070 vapor osmometer at $40{ }^{\circ} \mathrm{C}$ in water. Urea and $\alpha$-CD were used as the instruments standard. The positive-ion matrix assisted laser desorption ionization time-of-flight (MALDI-TOF) mass measurements were performed on a Shimadzu/KRATOS AXIMA-CFR spectrometer with 2,5-dihydroxybenzoic acid as a matrix.

\section{Materials.}

$\beta$-CD, 1-adamantane carboxylic acid (AdCA) and $\mathrm{NaOH}$ were obtained from Nacarai Tesque, Inc. 4Aminohydrocinnamic acid and 1-ethyl-3-(3-dimethylaminopropyl)carbodiimide hydrochloride $(\mathrm{EDC} \cdot \mathrm{HCl})$ were obtained from Tokyo Chemical Industry Co., Ltd.. Poly(ethylene glycol) (PEG) 600 diacid (MW = 600) was obtained from SIGMA-ALDRICH Corp.. PEG 3000 diacid (MW = 2925) was obtained from NOF CORPORATION.

\section{Synthesis.}

Mono-6-deoxy-6-( $\boldsymbol{p}$-tolylsulfonyl)- $\boldsymbol{\beta}$-CD (6-TsO- $\beta$-CD). This compound was prepared according to the method reported previously. ${ }^{1}$

4-Aminohydrocinnamic acid, sodium salt (AmHyCiONa). $\mathrm{NaOH}\left(4.8 \mathrm{~g}, 1.2 \times 10^{-1} \mathrm{~mol}\right)$ and 4Aminohydrocinnamic acid $\left(20 \mathrm{~g}, 1.2 \times 10^{-1} \mathrm{~mol}\right)$ were dissolved in EtOH $(300 \mathrm{~mL})$. The reaction was carried out with stirring under reflux for $1 \mathrm{~h}$. The precipitated product was filtered and washed with $\mathrm{EtOH}$, then dried under vacuum at $70{ }^{\circ} \mathrm{C}$. Yield, 90\%. ${ }^{1} \mathrm{H}$ NMR (DMSO- $\left.d_{6}, 400 \mathrm{MHz}\right): \delta 6.82(\mathrm{~d}, 2 \mathrm{H}$, $2 \mathrm{H}$ - of phenyl), $\delta 6.45$ (d, 2H, 3H- of phenyl), $\delta 4.69\left(\mathrm{~s}, 2 \mathrm{H}, \mathrm{NH}_{2}\right), \delta 2.57\left(\mathrm{t}, 2 \mathrm{H}, \mathrm{Ph}-\mathrm{CH}_{2}-\right), \delta 2.06(\mathrm{t}$, $2 \mathrm{H},-\mathrm{CO}-\mathrm{CH}_{2}-$ ).

Mono-6-deoxy-6-(4-aminohydrocinnamoyl)- $\beta$-CD (6-AmHyCiO- $\beta$-CD). 6-TsO- $\beta$-CD (15.0 g, 1.2 $\left.\times 10^{-2} \mathrm{~mol}\right)$ and AmHyCiONa $\left(6.5 \mathrm{~g}, 3.5 \times 10^{-2} \mathrm{~mol}\right)$ were dissolved in DMSO $(300 \mathrm{~mL})$. The reaction was carried out with stirring under heating at $80{ }^{\circ} \mathrm{C}$ for 3 days. After being cooled to room temperature, the solution was poured into acetone. The resulting precipitate was dried under vacuum to give crude product. The crude product was purified by DIAION HP-20 column chromatography. The 80/20 (water/methanol) eluent was concentrated and dried under vacuum to give 6-AmHyCiO- $\beta$-CD. Yield, $66 \%$. Positive ion MALDI-TOF MS: $\mathrm{m} / \mathrm{z} 1306.0\left(\mathrm{M}+\mathrm{Na}^{+}\right) .{ }^{1} \mathrm{H}$ NMR (DMSO- $\left.d_{6}, 400 \mathrm{MHz}\right): \delta 6.86(\mathrm{~d}$, $2 \mathrm{H}, 2 \mathrm{H}-$ of phenyl), $\delta 6.47(\mathrm{~d}, 2 \mathrm{H}, 3 \mathrm{H}-$ of phenyl), $\delta 5.76-5.63(\mathrm{~m}, 14 \mathrm{H}, \mathrm{O}(2) \mathrm{H}$ and $\mathrm{O}(3) \mathrm{H}$ of $\mathrm{CD}), \delta$ 4.82-4.78 (m, 7H, C(1)H of $\mathrm{CD}), \delta 4.52-4.10(\mathrm{~m}, 7 \mathrm{H}, \mathrm{O}(6) \mathrm{H}$ and $\mathrm{C}(6) \mathrm{H}$ of $\mathrm{CD}), \delta 3.84-3.16(\mathrm{~m}$, $\mathrm{C}(2) \mathrm{H}-\mathrm{C}(5) \mathrm{H}$ of $\mathrm{CD}$ overlaps with $\mathrm{HOD}), \delta 2.66\left(\mathrm{t}, 2 \mathrm{H}, \mathrm{Ph}-\mathrm{CH}_{2}-\right), \delta 2.53$ (t, 2H, $-\mathrm{CO}-\mathrm{CH}_{2}-$ overlaps with DMSO- $\left.d_{6}\right)$. Anal. Calcd for $\mathrm{C}_{51} \mathrm{H}_{79} \mathrm{O}_{36} \mathrm{~N} \cdot 6\left(\mathrm{H}_{2} \mathrm{O}\right)$ : C, 44.06; H, 6.60; N, 1.01. Found: C, 43.79; $\mathrm{H}$, $6.47 ; \mathrm{N}, 1.20$. 
Mono-6-deoxy-6-[4-poly(ethylene glycol) 600 acid-hydrocinnamoyl]- $\beta$-CD (6-PEG600acidHyCiO- $\beta$-CD). PEG 600 diacid $\left(2340 \mathrm{mg}, 3.9 \times 10^{-3} \mathrm{~mol}\right)$ and EDC. $\mathrm{HCl}\left(1121 \mathrm{mg}, 5.9 \times 10^{-3} \mathrm{~mol}\right)$ was dissolved in water/DMF $(=30 / 70)$ with stirring at $5{ }^{\circ} \mathrm{C}$. After 1 hour, a solution of 6 -AmHyCiO- $\beta$-CD $\left(1000 \mathrm{mg}, 7.8 \times 10^{-4} \mathrm{~mol}\right) \mathrm{in}$ water/DMF was added to the solution. It was allowed to warm to room temperature and stirred 3 days. Insoluble material was removed by filtration, and the filtrate was concentrated and poured in acetone. The precipitate was collected and washed with acetone. The crude product was purified by a gradient HPLC (eluted with water/acetonitrile). Yield, 35\%. Positive ion MALDI-TOF MS ( $n$; number of ethylene glycol units in PEG): $\mathrm{m} / \mathrm{z} 1727.6[\mathrm{M}(n=7)+\mathrm{Na}]^{+}, 1771.2$ $[\mathrm{M}(n=8)+\mathrm{Na}]^{+}, 1816.6\left[\mathrm{M}(n=9)+\mathrm{Na}^{+}, 1859.21[\mathrm{M}(n=10)+\mathrm{Na}]^{+}, 1904.7[\mathrm{M}(n=11)+\mathrm{Na}]^{+}\right.$, $1948.4[\mathrm{M}(n=12)+\mathrm{Na}]^{+}, 1991.8[\mathrm{M}(n=13)+\mathrm{Na}]^{+}, 2034.3[\mathrm{M}(n=14)+\mathrm{Na}]^{+}, 2081.6[\mathrm{M}(n=15)$ $+\mathrm{Na}]^{+}, 2123.9[\mathrm{M}(n=16)+\mathrm{Na}]^{+} .{ }^{1} \mathrm{H}$ NMR $\left(\mathrm{DMSO}-d_{6}, 400 \mathrm{MHz}\right): \delta 9.52(\mathrm{~s}, 1 \mathrm{H},-\mathrm{NHCO}-), \delta 7.52(\mathrm{~d}$, $2 \mathrm{H}, 3 \mathrm{H}-$ of phenyl), $\delta 7.16(\mathrm{~d}, 2 \mathrm{H}, 2 \mathrm{H}-$ of phenyl), $\delta 6.00-5.70(\mathrm{~m}, 14 \mathrm{H}, \mathrm{O}(2) \mathrm{H}$ and $\mathrm{O}(3) \mathrm{H}$ of $\mathrm{CD}), \delta$ 4.85-4.80 (m, 7H, C(1)H of $\mathrm{CD}), \delta 4.45-4.15\left(\mathrm{~m}, 7 \mathrm{H}, \mathrm{O}(6) \mathrm{H}\right.$ and $\mathrm{C}^{\prime}(6) \mathrm{H}$ of $\left.\mathrm{CD}\right), \delta 4.05(\mathrm{~s}, 4 \mathrm{H}$, $-\mathrm{CO}-\mathrm{CH}_{2}-\mathrm{O}-$ of PEG), $\delta$ 3.85-3.17 (m, $\mathrm{C}(2) \mathrm{H}-\mathrm{C}(5) \mathrm{H}$ of $\mathrm{CD}$ and $-\mathrm{CH}_{2}-$ of PEG overlaps with $\mathrm{HOD}), \delta 2.80\left(\mathrm{t}, 2 \mathrm{H}, \mathrm{Ph}-\mathrm{CH}_{2}-\right), \delta 2.62\left(\mathrm{t}, 2 \mathrm{H},-\mathrm{CO}-\mathrm{CH}_{2}-\right.$ overlaps with DMSO- $\left.d_{6}\right)$.

Mono-6-deoxy-6-[4-poly(ethylene glycol) 3000 acid-hydrocinnamoyl]- $\beta$-CD (6-PEGacid3000HyCiO- $\beta$-CD). Synthesis of 6-PEGacid3000-HyCiO- $\beta-\mathrm{CD}$ is essentially the same way with 6PEG600acid-HyCiO- $\beta$-CD. Yield, $21 \%$. Positive ion MALDI-TOF MS ( $n$; number of ethylene glycol units in PEG): $\mathrm{m} / \mathrm{z} 3837.1[\mathrm{M}(n=56)+\mathrm{Na}]^{+}, 3881.6[\mathrm{M}(n=57)+\mathrm{Na}]^{+}, 3926.5[\mathrm{M}(n=58)+\mathrm{Na}]^{+}$, $3971.2[\mathrm{M}(n=59)+\mathrm{Na}]^{+}, 4015.4[\mathrm{M}(n=60)+\mathrm{Na}]^{+}, 4059.7[\mathrm{M}(n=61)+\mathrm{Na}]^{+}, 4102.6[\mathrm{M}(n=62)$ $+\mathrm{Na}]^{+}, 4188.0[\mathrm{M}(n=63)+\mathrm{Na}]^{+}, 4234.8[\mathrm{M}(n=64)+\mathrm{Na}]^{+}, 4276.6[\mathrm{M}(n=65)+\mathrm{Na}]^{+}, 4322.1[\mathrm{M}$ $(n=66)+\mathrm{Na}]^{+}, 4365.8[\mathrm{M}(n=67)+\mathrm{Na}]^{+}, 4412.0[\mathrm{M}(n=68)+\mathrm{Na}]^{+}, 4456.7[\mathrm{M}(n=69)+\mathrm{Na}]^{+}$, $4497.7[\mathrm{M}(n=70)+\mathrm{Na}]^{+}, 4537.9[\mathrm{M}(n=71)+\mathrm{Na}]^{+}, 4585.3[\mathrm{M}(n=72)+\mathrm{Na}]^{+}, 4628.8[\mathrm{M}(n=73)$ $+\mathrm{Na}]^{+} .{ }^{1} \mathrm{H}$ NMR (DMSO- $\left.d_{6}, 400 \mathrm{MHz}\right): \delta 9.50(\mathrm{~s}, 1 \mathrm{H},-\mathrm{NHCO}-), \delta 7.52$ (d, 2H, 3H- of phenyl), $\delta$ $7.17(\mathrm{~d}, 2 \mathrm{H}, 2 \mathrm{H}-$ of phenyl), $\delta 5.90-5.65(\mathrm{~m}, 14 \mathrm{H}, \mathrm{O}(2) \mathrm{H}$ and $\mathrm{O}(3) \mathrm{H}$ of $\mathrm{CD}), \delta 4.86-4.80(\mathrm{~m}, 7 \mathrm{H}$, $\mathrm{C}(1) \mathrm{H}$ of $\mathrm{CD}$ ), $\delta 4.46-4.12\left(\mathrm{~m}, 7 \mathrm{H}, \mathrm{O}(6) \mathrm{H}\right.$ and $\mathrm{C}^{\prime}(6) \mathrm{H}$ of $\left.\mathrm{CD}\right), \delta 4.05$ (s, 4H, $\left.-\mathrm{CO}-\mathrm{CH}_{2}-\mathrm{O}-\mathrm{of} \mathrm{PEG}\right), \delta$ 3.85-3.12 (m, $\mathrm{C}(2) \mathrm{H}-\mathrm{C}(5) \mathrm{H}$ of $\mathrm{CD}$ and $-\mathrm{CH}_{2}-$ of $\mathrm{PEG}$ overlaps with $\left.\mathrm{HOD}\right), \delta 2.80(\mathrm{t}, 2 \mathrm{H}$, $\left.\mathrm{Ph}-\mathrm{CH}_{2}-\right), \delta 2.62\left(\mathrm{t}, 2 \mathrm{H},-\mathrm{CO}-\mathrm{CH}_{2}-\right.$ overlaps with DMSO- $\left.d_{6}\right)$. 
Characterization of 6-AmHyCiO- $\beta$-CD, 6-PEG600acid-HyCiO- $\beta$-CD and 6-PEG3000acidHyCiO- $\beta$-CD.
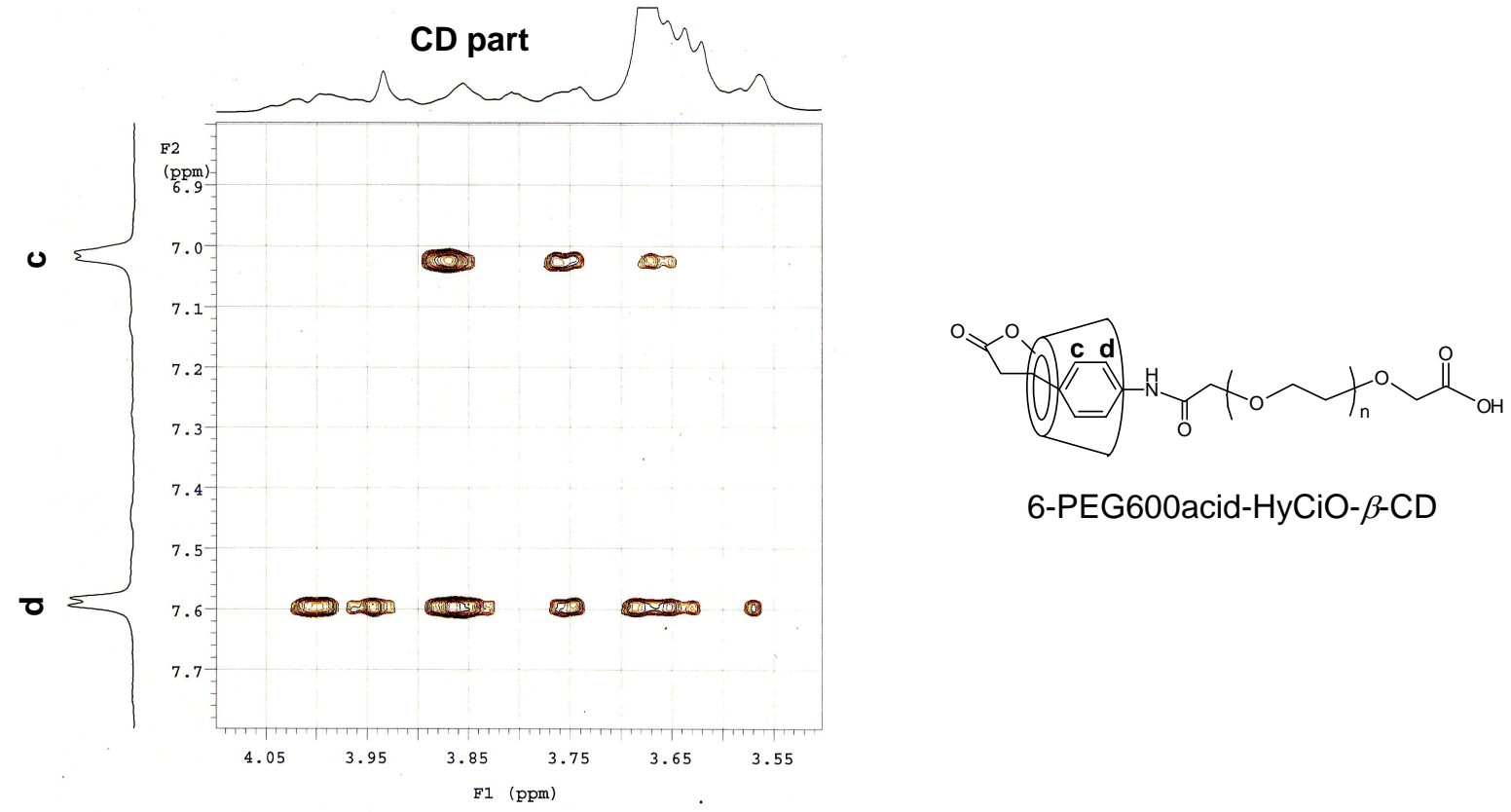

6-PEG600acid-HyCiO- $\beta$-CD

Figure S1. 2D ROESY NMR spectrum of 6-PEG600acid-HyCiO- $\beta$-CD in $\mathrm{D}_{2} \mathrm{O}$ at $30{ }^{\circ} \mathrm{C}$.
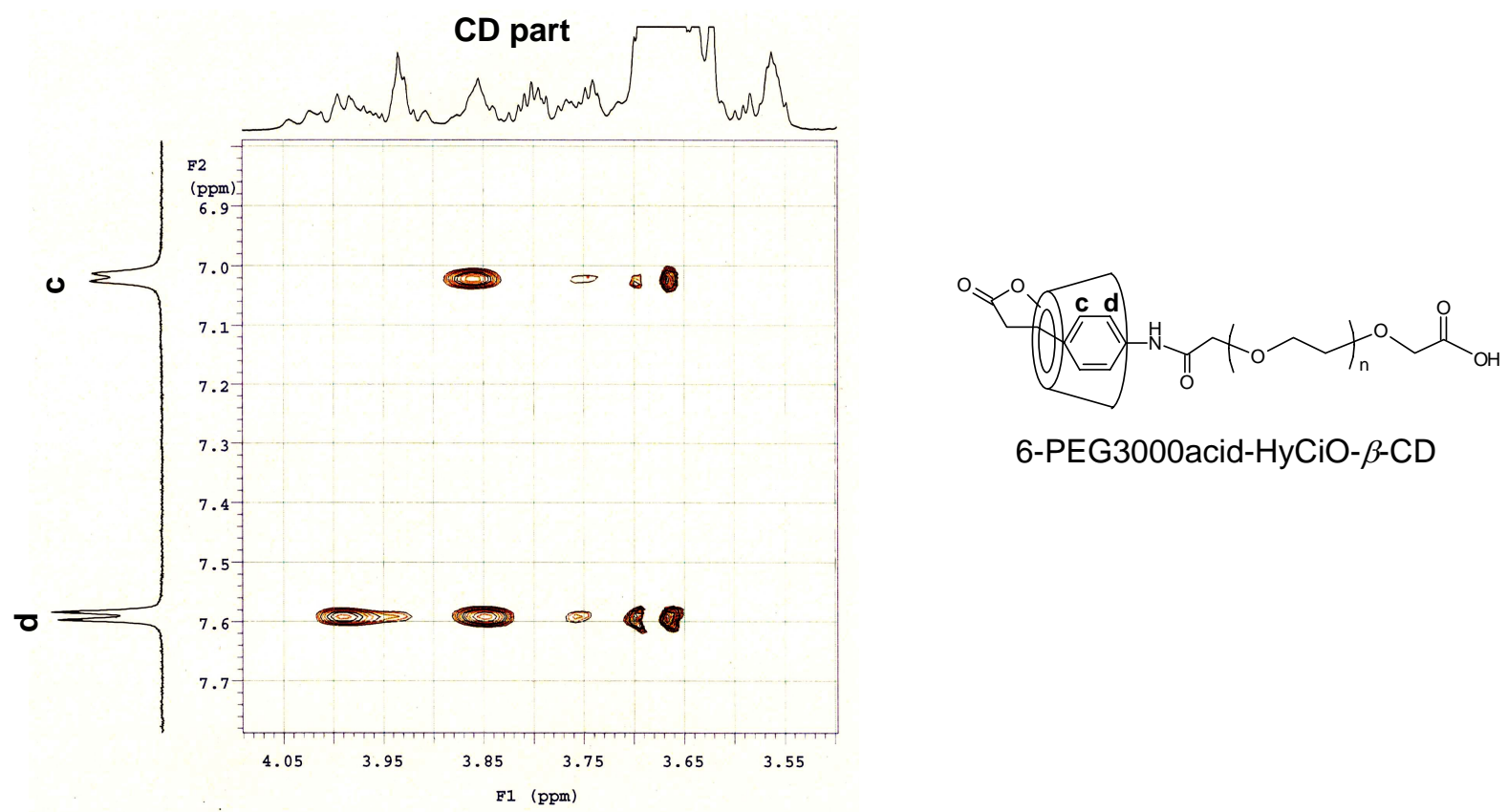

6-PEG3000acid-HyCiO- $\beta$-CD

Figure S2. 2D ROESY NMR spectrum of 6-PEG3000acid-HyCiO- $\beta$-CD in $\mathrm{D}_{2} \mathrm{O}$ at $30^{\circ} \mathrm{C}$. 


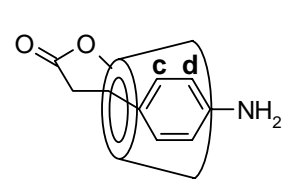

6-AmHyCiO- $\beta$-CD

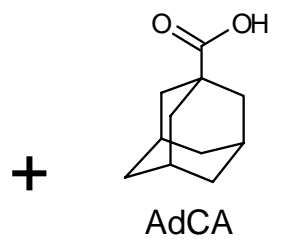

c d

a)

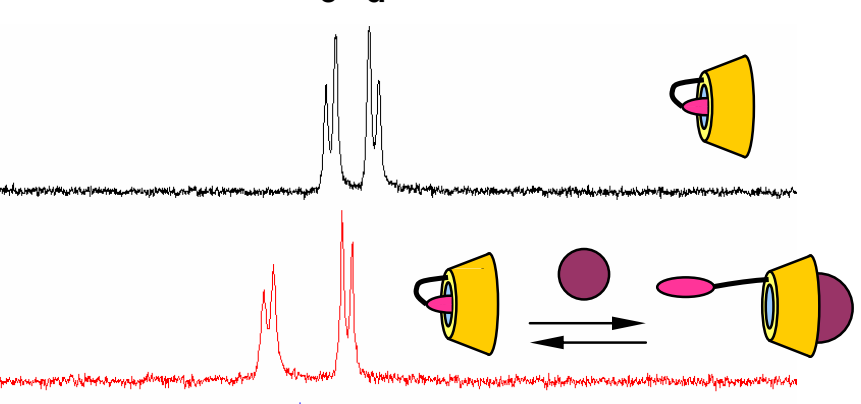

c)

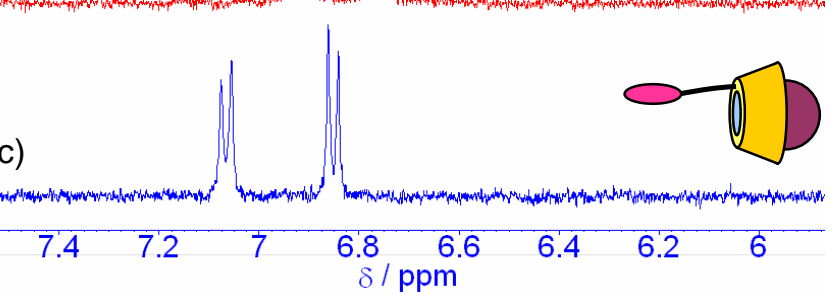

Figure S3. NMR spectra and proposed structures of 6-AmHyCiO- $\beta$-CD in $\mathrm{D}_{2} \mathrm{O}$ at $30{ }^{\circ} \mathrm{C}$ (a) in the absence of AdCA, (b) in the presence of a half amount of AdCA, and (c) in the presence of an equal amount of AdCA.

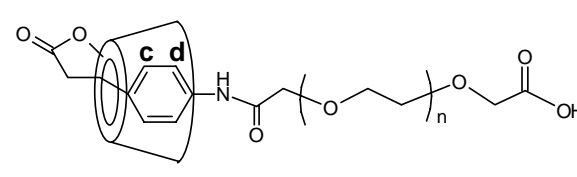

6-PEG600acid-HyCiO- $\beta$-CD<smiles>O=C(O)C12CC3CC(CC(C3)C1)C2</smiles>

AdCA

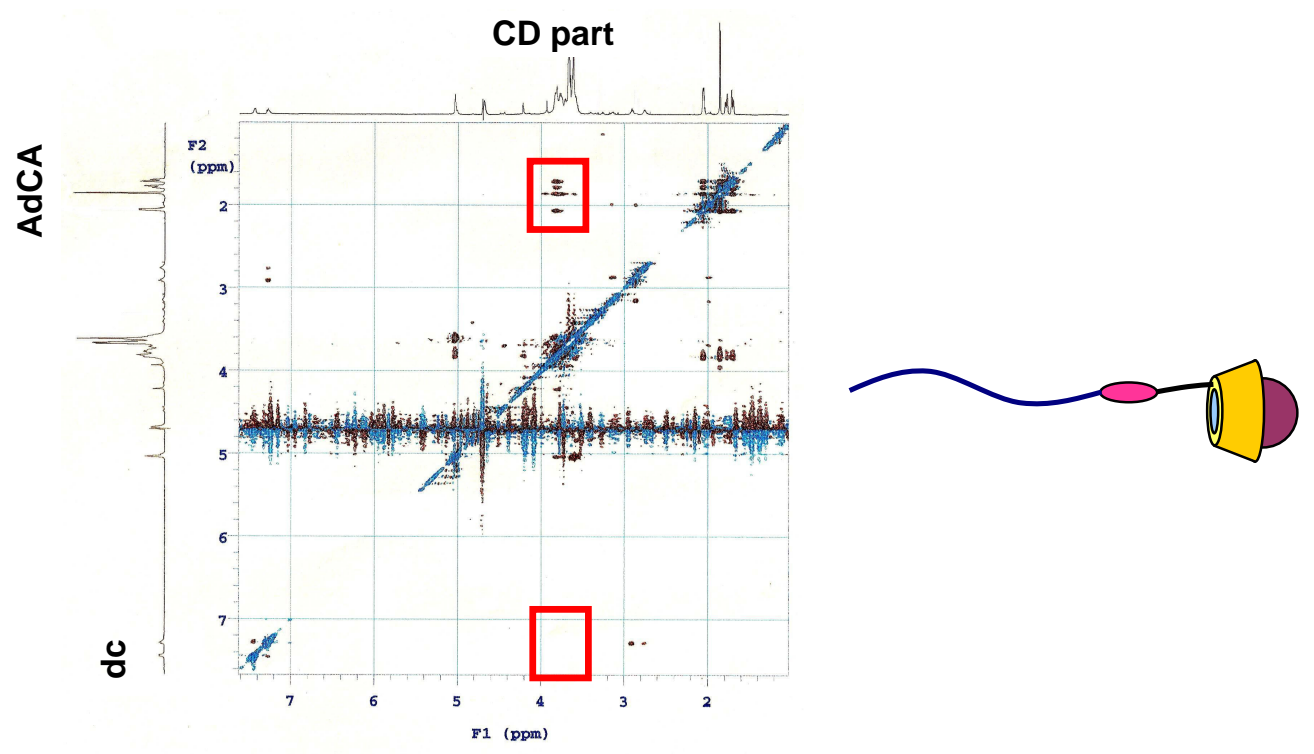

Figure S4. 2D ROESY NMR spectrum of 6-PEG600acid-HyCiO- $\beta$-CD in the presence of an equal amount of $\mathrm{AdCA}$ in $\mathrm{D}_{2} \mathrm{O}$ at $30^{\circ} \mathrm{C}$. 


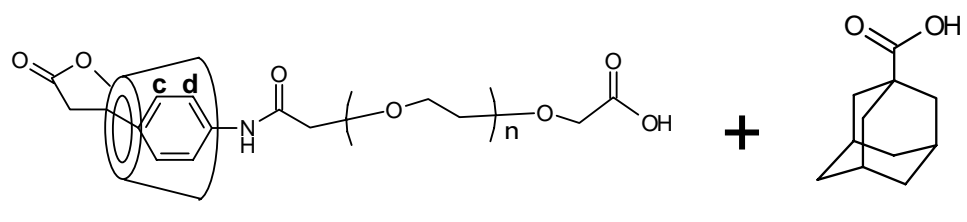

6-PEG3000acid-HyCiO- $\beta$-CD AdCA

a)<smiles>[AlH2]</smiles>
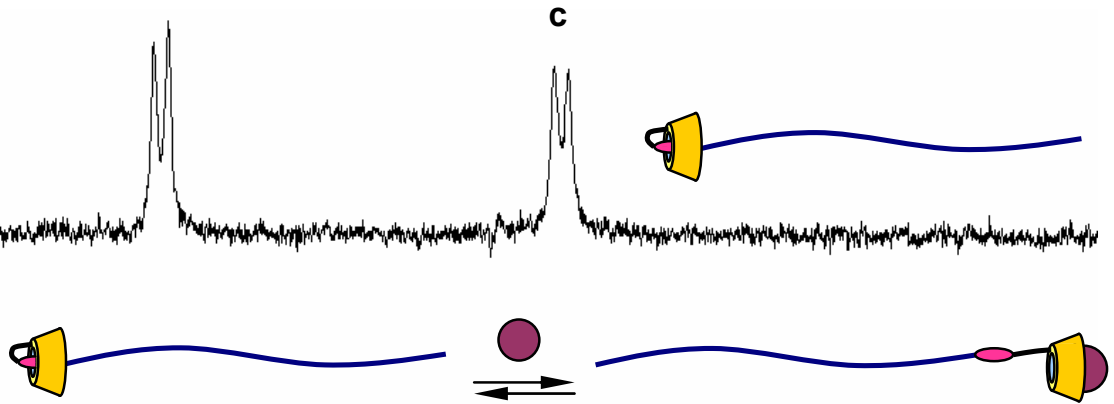

b)

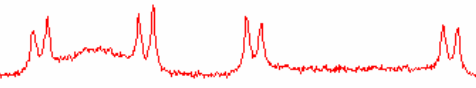

c)

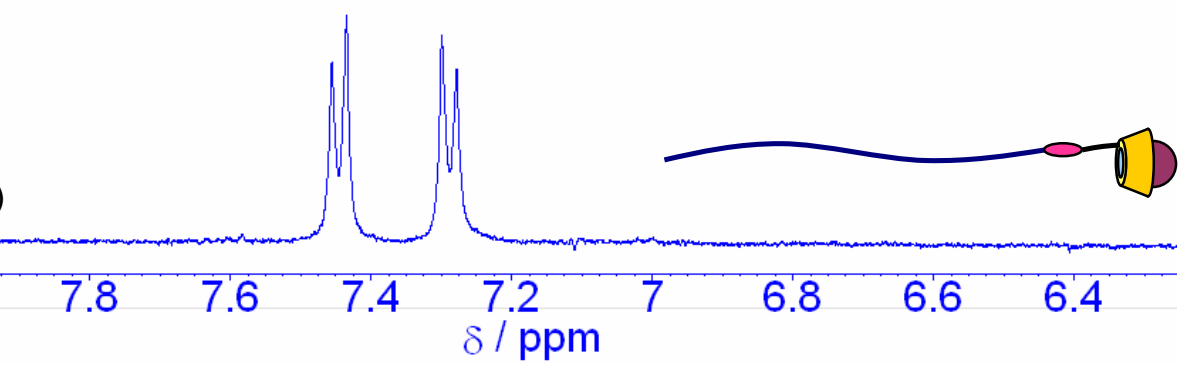

Figure S5. NMR spectra and proposed structures of 6-PEG3000acid-HyCiO- $\beta$-CD in $\mathrm{D}_{2} \mathrm{O}$ at $30{ }^{\circ} \mathrm{C}$ (a) in the absence of AdCA, (b) in the presence of a half amount of $\mathrm{AdCA}$, and (c) in the presence of an equal amount of AdCA.

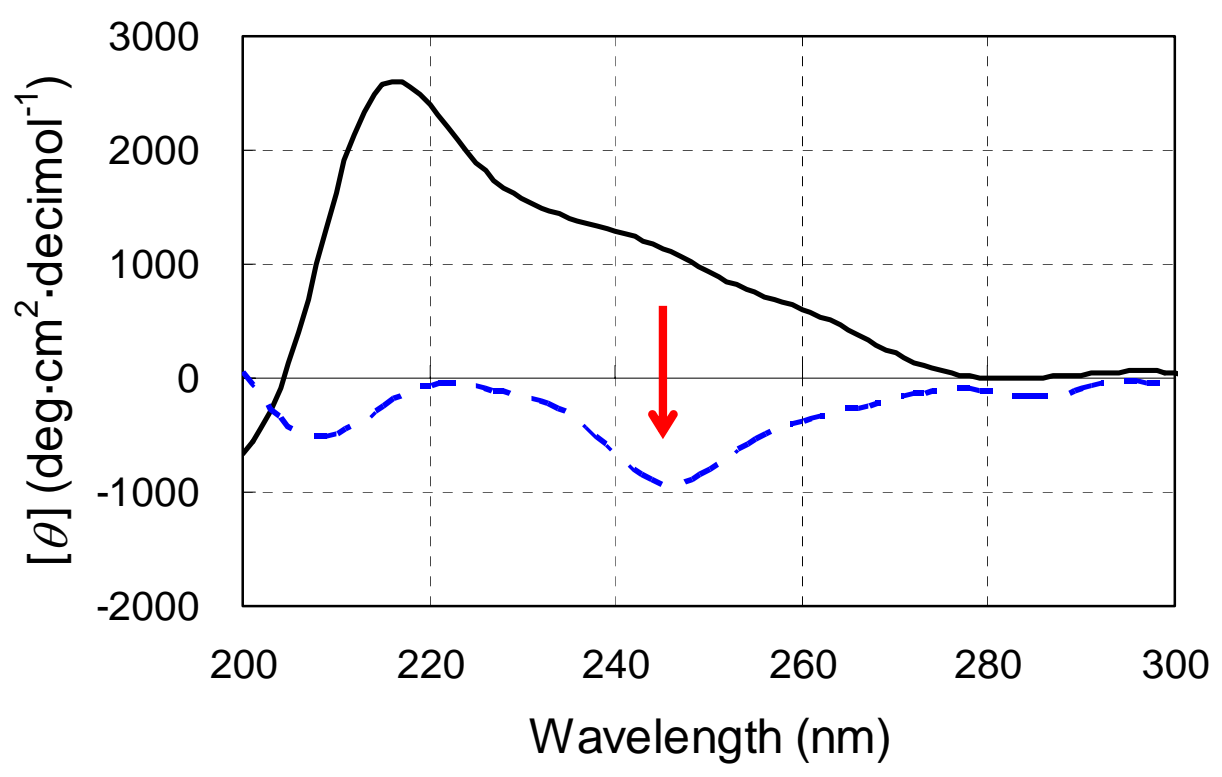

Figure S6. Circular dichroism spectra of 6-PEG3000acid-HyCiO- $\beta$-CD in aqueous solutions (solid line) and in the presence of an equal amount of AdCA (dashed line). 


\section{Variable-temperature NMR measurement.}

The coalescence temperature $T_{\mathrm{c}}$ is estimated on the coalescence signal $\mathbf{c}$ with waveform separation. (It is considerable the signals indicated by asterisks $(*)$ come from the species that do not participate in conformational exchange because these signals do not coalesce even at high temperature.)

The conformational exchange rate constants $k_{\mathrm{c}}$ at $T_{\mathrm{c}}$ were obtained by using the approximate expression. $^{2}$

$$
k_{\mathrm{c}}=\frac{\pi \Delta v}{\sqrt{2}}
$$

$\Delta v$. the chemical shift difference between the target split signals

The free energy of activation for conformational exchange at coalescence temperature $\Delta G^{\neq}$and the extrapolated values of the exchange rate constants $k_{\mathrm{ex}}$ at $30^{\circ} \mathrm{C}$ were obtained from the Eyring equation.

$$
k=\left(\frac{k_{\mathrm{B}} T}{h}\right) \exp \left(-\frac{\Delta G^{\neq}}{R T}\right)
$$

$k_{\mathrm{B}}$ : the Boltzmann constant

$h$ : the Planck constant

$R$ : the gas constant

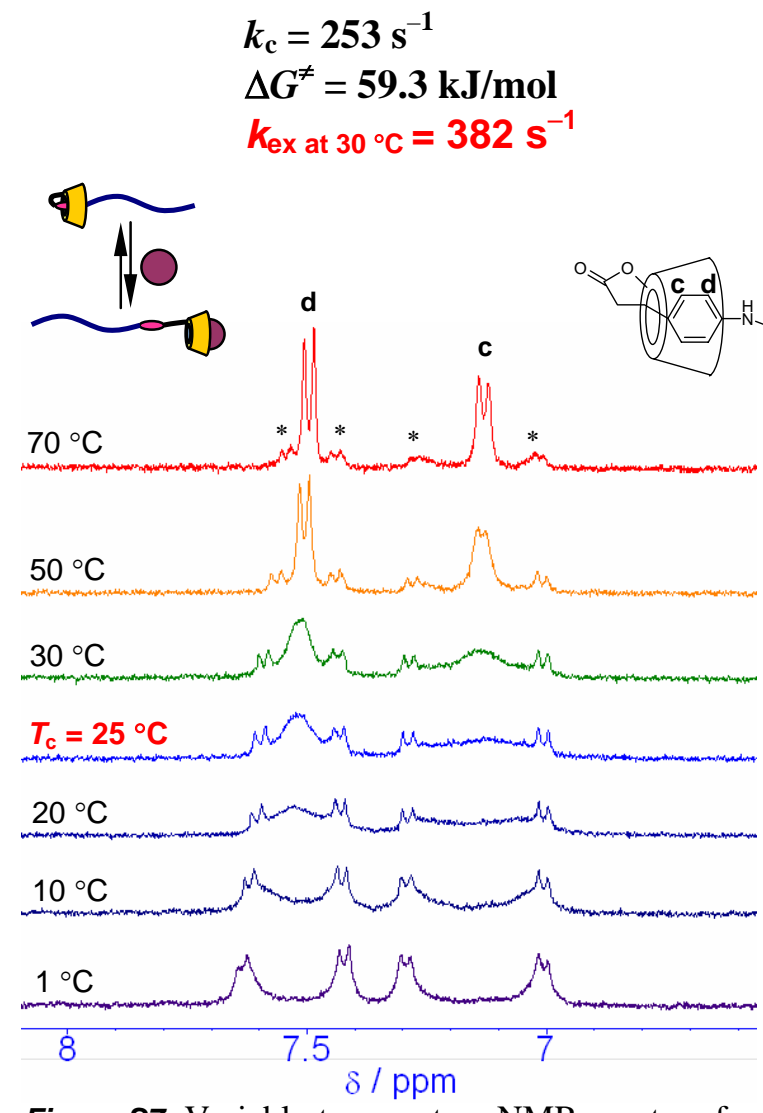

Figure S7. Variable-temperature NMR spectra of 6-PEG600acid-HyCiO- $\beta$-CD in the presence of a half amount of AdCA in $\mathrm{D}_{2} \mathrm{O}$.

$$
\begin{aligned}
& k_{\mathrm{c}}=247 \mathrm{~s}^{-1} \\
& \Delta G^{\neq}=61.2 \mathrm{~kJ} / \mathrm{mol} \\
& k_{\text {ex at } 30^{\circ} \mathrm{C}}=177 \mathrm{~s}^{-1}
\end{aligned}
$$

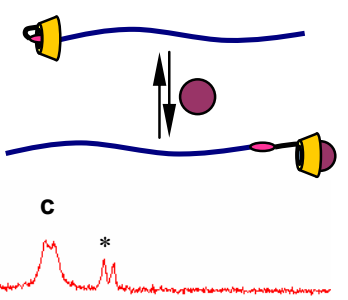

$50^{\circ} \mathrm{C}$

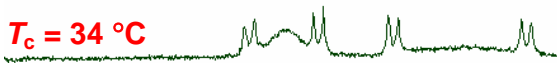

$30^{\circ} \mathrm{C}$

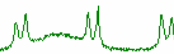
$M$

$20^{\circ} \mathrm{C}$ $M M M$

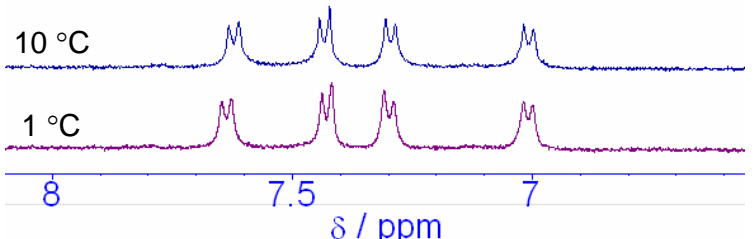

Figure S8. Variable-temperature NMR spectra of 6-PEG3000acid-HyCiO- $\beta$-CD in the presence of a half amount of AdCA in $\mathrm{D}_{2} \mathrm{O}$. 

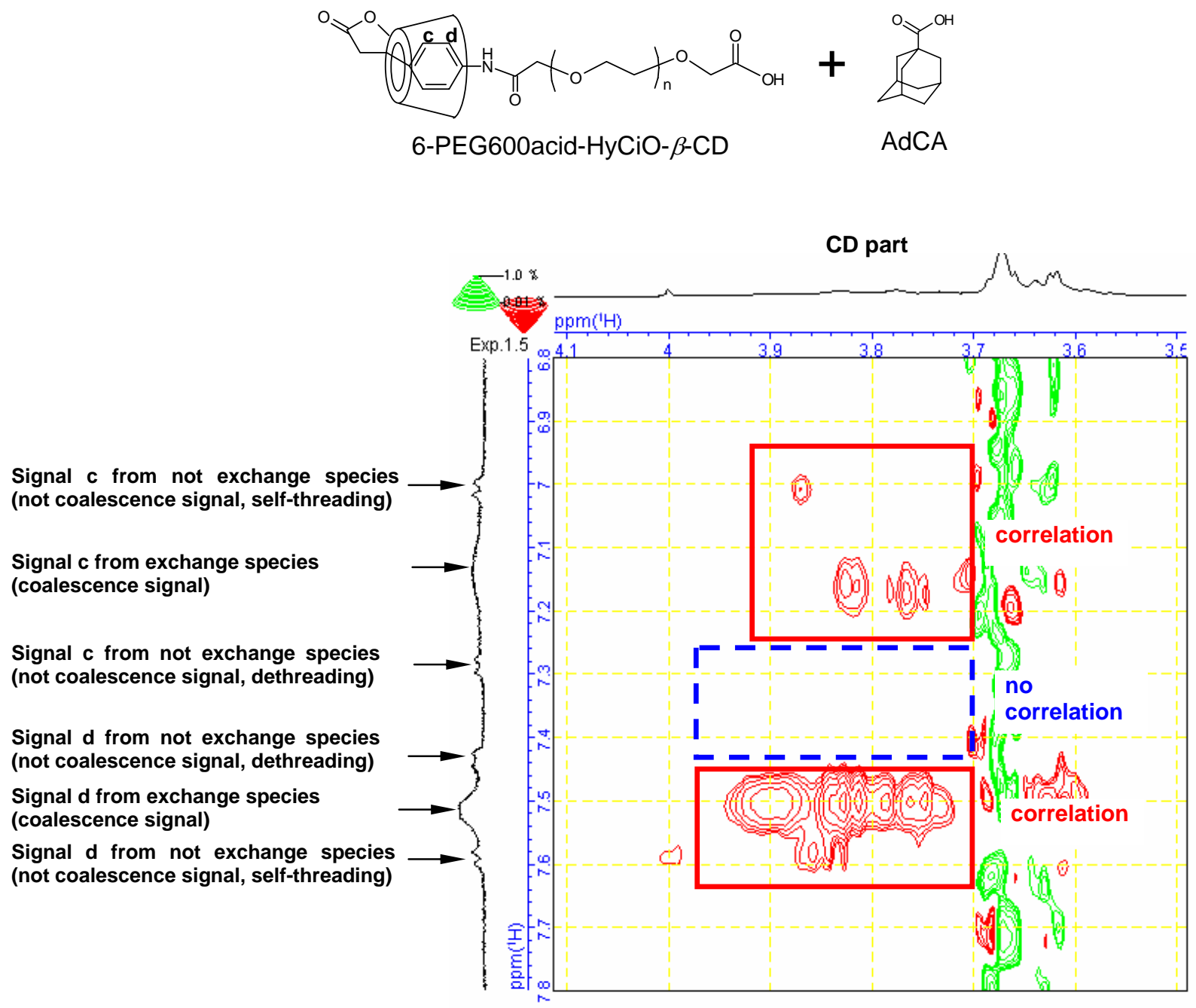

Figure 59. Partial 2D ROESY NMR spectrum of 6-PEG600acid-HyCiO- $\beta$-CD in the presence of a half amount of AdCA in $\mathrm{D}_{2} \mathrm{O}$ at $30^{\circ} \mathrm{C}$.

\section{References}

(1) Takahashi, K.; Hattori, K.; Toda, F. Tetrahedron Lett. 1984, 25, 3331-3334.

(2) Sutherland I. O. Annu. Rep. NMR Spectrosc. 1971, 4, 71-235. 